\title{
Ecotourism: A Panacea towards the Sustaining Biodiversity-A Case Study on Major Tourist Destinations of Coastal Purba Medinipur, West Bengal, India
}

\author{
Pijush Kanti Dandapath ${ }^{1}$, Dr. Gone Oraon ${ }^{2}$ \\ ${ }^{\mathbf{1}}$ Assistant Professor \& Head,Dept. of Geography, Bajkul Milani Mahavidyalaya, Purba Medinipur, West Bengal and Research Scholar, \\ Department of Geography, Ranchi University, Ranchi, Jharkhand, India \\ ${ }^{2}$ Assistant Professor and Head, Dept. of Geography, Karam Chand Bhagat (KCB) College, Bero, Ranchi, Jharkhand India
}

\begin{abstract}
Over the year Tourism cropped up to be a revolutionizing phenomenon and it is emerging as a catalyst of the development process by promotes employment opportunities and augments foreign exchange of a country. But, if the development of tourism industry is not properly planned and managed, tourism itself produces a myriad of negative effects include the every tourist destination. Coastal tract of Purba Medinipur is an attractive combination of sea and land where the casuarinas and mangrove forest are whispering, sea are roaring, the flora and fauna are blooming and where visitors can rejuvenate yourself in the company of Sea, Sand and Sun in the pristine open air. But the feature is seen that the coastal tract attract a large number of tourist each year. So greater pressure of population inevitably puts more pressure on environment which has led to the deterioration in environmental quality and also put detrimental effect on coastal biodiversity in Purba Medinipur.
\end{abstract}

Keywords: Tourism, Urbanisation, Ecotourism, Coastal tract, Biodiversity, Environment

\section{Introduction}

At present Technology, Telecommunication (basically IT Sector) and Tourism are the major segments for the development of economy of a country. One of them Tourism is one of the world's largest industrial segments of the source of income generator. It is a major contributor to foreign exchange earnings provides employment to millions directly and indirectly (Globally, tourism and related economic activities generate $11 \%$ of global domestic product, employ 200 million people and transport nearly 700 million international travellers per year. These figure expected to double by 2020 especially in some of the world's least developed countries-Cater, E. And Lowman, G.:2013) and acts as a vehicle for infrastructure development as a big way while damaging the natural environment too. Due to huge infrastructural (mainly concretisation) and resource demands of tourism (e.g. water consumption, waste generation, energy use to accelerated road transport, huge no. of hotels, amusement facilities and also illegal encroachment of small traders) can have bad impacts upon local communities and it has also led to the deterioration in environmental quality by direct and indirect way if it is not properly managed; as like indiscriminate expansion of tourism industry which is the common feature of maximum tourist destination including Tourist Sectors of Coastal Purba Medinipur of West Bengal in India.

Indiscriminate expansion of the tourism industry has resulted in some ecological and cultural damages to the host country. For this reason, after 1980s the concept of the Ecotourism has been popularised rapidly by the Hector Ceballos Lascurain in 1983. Initially the term Ecotourism (a part of Tourism) used as - nature based tourism and it is an effective instrument for enhancing method of conservation of environment, income generating activity of local population and rejuvenates man's sprit to explore nature again and again. Thus the definition of ecotourism, given by the different scholars, more or less co-here around three criteria: i). Attraction should be predominantly nature based; ii). Visitors interactions with those attractions should be focused on learning or education and iii) Experience and product management should follow principles and practices associated with ecological, socio-cultural and economic sustainability.

The Government of West Bengal recognising the importance of the tourism industry and has taken many policy measures to the development of tourism destination from Pahar (Hill) to Samudra (Sea). But in maximum tourism field among all tourism centre, it is generally found that the tourism of West Bengal are characterised by invariably leads to accelerated road transport, indiscriminate expansion of hotel industry, damping of waste disposal on and outside the road or anywhere and also grown up illegal encroachment of small traders. The development of coastal tourism destinations including coastal Purba Medinipur (like Digha, Sankarpur, Tajpur, Mandermoni etc.) of west Bengal are also maintained the same character. Whereas West Bengal has golden opportunities for the establishment of ecotourism instead of indiscriminate expansion or development of tourism destination due to characterised by Royal Bengal Tiger, Mangrove Forest (Sundarban- World largest Zoogeographical Region), wide and hard beaches (Bay of Bengal Coastal Tract like Digha, Sankarpur, Tajpur, Mandermoni, Sagar Island, Bakkhali etc.) of the extreme Southern part to Dry Deciduous Forest and Indian Elephant of Western part and One Horned Rhinocess and dense Deciduous Forest and Ever-green Forest (mixed jungle) and Hill town of the Eastern Himalayan Region and its Foot-Hill 


\section{International Journal of Science and Research (IJSR) \\ ISSN (Online): 2319-7064}

Index Copernicus Value (2013): 6.14 | Impact Factor (2015): 6.391

(Tarai and Dooars) in Northern part. Among these destinations of tourist, Tourist Sectors of Coastal Purba Medinipur of South Bengal has a super natural capacity to prove her-self a complete Ecotourism destination, where natural scenario and high degree of biodiversity has kept wide open. So introduce ecotourism to preserve travel to natural areas to appreciate the cultural and natural history of the environment, taking care not to disturb the integrity of the ecosystem, while creating economic opportunities that make conservation and protection of natural resources advantage to local people of those tourist destinations.

\section{Methodology}

The present paper intended to be empirical study designed for a Micro Level investigation this involves gathering of information and collection of data at both case study and survey method. Degree of Tourism Industry will be analyzed from the data (which collect from the Statistical Hand Book of East Medinipur, Economic Review of West Bengal and Digha SankarPur Development Authority Office) and its impact will be drawn through the intensive field survey.

\section{Study Area}

The Purba Medinipur Coast with a length about $60 \mathrm{~km}$ with covering the area about $27 \%$ of the West Bengal Coastal Tract extends from the mouth of the river Subarnarekha on the West (bordering the state of Orissa) to the west bank of Hooghly Estuary between longitude $87^{\circ} 30^{\prime} \mathrm{E}$ and latitude $21^{\circ} 37.012^{\prime} \mathrm{N}$ to longitude $88^{0} 5^{\prime} \mathrm{E}$ latitude $22^{0} 2^{\prime} \mathrm{N}$.

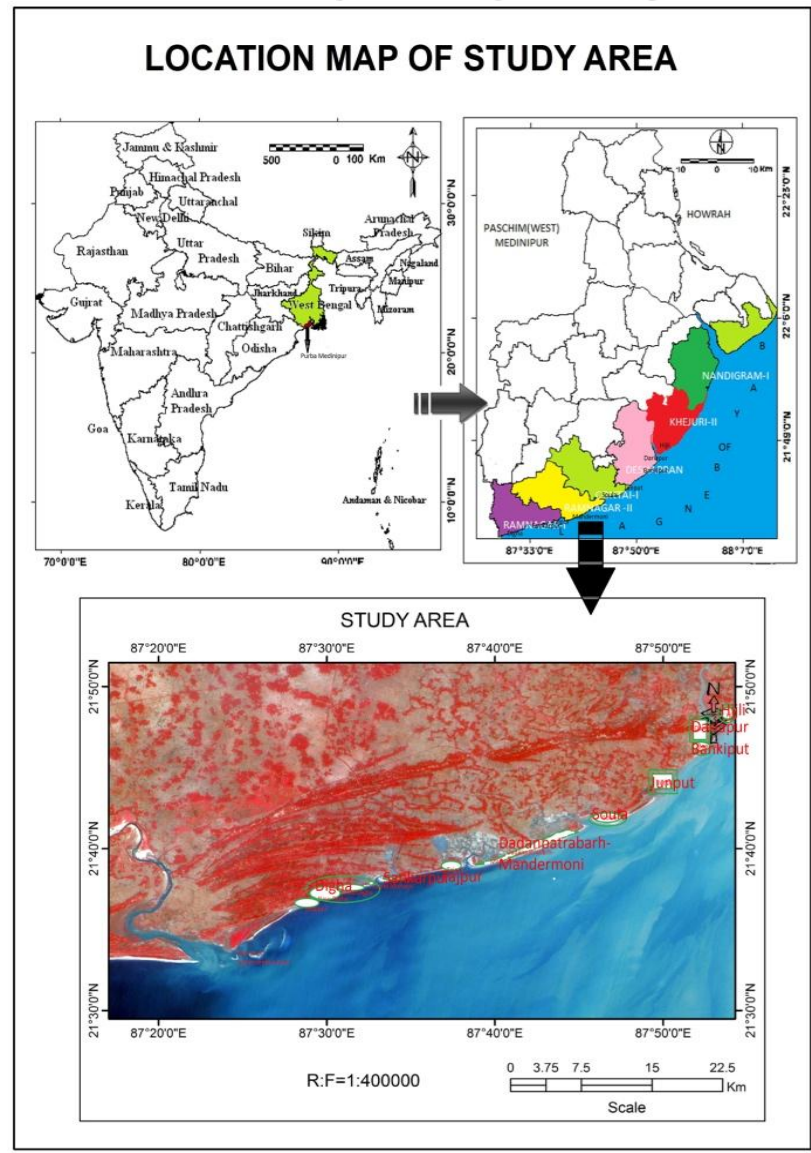

\section{Objectives}

For the last two decades the coastal tourist destination of Purba Medinipur coast among all coastal areas of West Bengal faced a rapid growth of mass tourism. Large flow of recreational tourist as well as excursionists visits the popular coastal tourist destination of Purba Medinipur coastal areas like Digha, Sankarpur, Tajpur, MandermoniDadanpatrabarh, Hijli etc for recreation and picnicking which has created huge pressure on the fragile ecosystem of the coast. The loose beaches are becoming more and more vulnerable. Uncontrolled and illegal construction of hotels and resorts, tapping up huge groundwater as well as the heaps of garbage are destroying the scenic beauty and purity of the beaches along with severe erosion of the same. In this context the author has tried to assess the extent of tourism development in the coastal tract of Purba Medinipur along with the major burning issues relating to this mass development of tourism. So the objectives of the present research work are:

- Extent of coastal ecotourism potential and development in the coastal Purba Medinipur.

- Spatial patterns of Coastal tourism places, and the environment concerns of the coastal areas.

- Share insight and experience to the local community, diffuse the light of development in the remote areas of coastal tract.

- Management of coastal areas in the line of sustainable ecotourism, and open the new visitors of revenue through the eco-tourism.

- Enhanced the visitor's satisfaction, sustainable local resource use and to suggest to the Govt., N.G.O. and tourism Dept. for the best planning and development of Ecotourism destinations.

\section{Basic physical feature to promote the development of tourism Industry}

Coastal Medinipur of West Bengal has golden opportunities for the development of tourism industry due to characterised by the Mangrove forest, several wide and hard beaches of attractions (like Digha, Sankarpur, Tajpur, Mandermoni, Juneput, Bankiput etc.) where the sightseer play and enjoy romance with sun, sand and sea in the sea beaches and different types of aquatic life, flora and fauna, rolling seas, sand dunes, casuarinas forest, red crabs, eye catching beauty of scenario which has kept her doors wide open. Beside these, there are varieties of trees, shrubs, climbers, herbs, medicinal plants and birds and also aquatic flora and fauna etc. are creating a colourful spectrum of bio-diversity

\section{Present developmental situation of different tourist sectors:}

Different developmental feature of some selected tourist sectors of Purba Medinipur are characterised as follows;

\section{A. Digha-Sankarpur Tourist Sector}

It is located from mouth of river Subarnarekha (Orissa Border) to Jaldha Mouza occupied the area about $2.5 \mathrm{~km}$ to $3 \mathrm{~km}$ width from low tide line and length is $14 \mathrm{~km}$. It mainly consists of sandy beaches, tidal bars, sand flats, coastal 


\section{International Journal of Science and Research (IJSR) \\ ISSN (Online): 2319-7064 \\ Index Copernicus Value (2013): 6.14 | Impact Factor (2015): 6.391}

dunes, inlets and fishing harbour (Sankarpur Fishing Harbour) etc. so this sector developed as tourist destination and attracts large holiday crowds, due to visitor's gathering to feel of rolling seas, sand dunes, casuarinas forest, red crabs etc and wide and hard beach.

This sector is the second highest revenue earning tourist destination of West Bengal next to Darjeeling hill resort. Picnicking under the shades of casuarinas forest on the dune surface ( both the coast of New Digha-Udaypur Beach and Sankarpur), walking and bird watching on the sand dunes(both old digha to new digha-udaypur beach and Sankarpur beach), Bathing in the sea water (basically new Digha some cases at Sankarpur due to restriction at old Digha), Motor cycle and also car driving and horse riding(New Digha-Udaypur beach and in the cases of old Digha it can found during low tide) are the major features of recreational exploitation by trippers (Daily Tourist) and tourists (stay at least or more than 24 hours) of the coast along this sea side tourist destination. Beside these features, Digha alone attract about more than 10 lakhs tourist per year (including domestic, national and foreigner) and Sankarpur 2.5 to 3lakhs per year and local population rapidly increased by both high birth rate and migrating population due to avail different economic facilities, with time (in 1971 it is approximately 14692 to 46532 population in 2011) so greater pressure of population, Digha has gradually developed by destroyed the casuarinas forest, shifted sand dunes and also mangrove forest with characterised the indiscriminate expansion of concretization (more than 480 Hotel \& Resorts, amusement park etc) just within few hundred metres and also damping waste garbage.

Marine life on the beaches of Digha coast were major attraction besides the vast expanse of the beach-line itself only a few years ago. The coastal town of Digha has changed from a small village to a tourist resort over a period of four decades. Initially, lack of communication and transport had kept the influx of the tourists at a low order. During the last four decades road connections have improved and a fleet of transport operations led to significant influx of tourists, which in turn necessitated development of hotels, holiday houses, private lodges, etc. Such a development took place without appropriate land use planning. The Geological Survey of India in its report on the Digha coastal belt pointed out that the active processes of erosion and accretion have been accelerated by several manmade interventions including removal of sand dunes, leading to mushrooming of construction near the coastline. The exact impact of tourism on the coastal belt of Digha cannot be quantified but, the continuing dumping of solid waste and raw sewage in the coastal water bear testimony to an alarming situation which increases with every tourist season.

The Digha Development Authority has finally initiated a land use plan on a sectoral approach, but the concept of coastal zone regulation was not incorporated during the preparation of the said plan. The natural calamities during the cyclonic conditions witnessed in the monsoon, 1989 has further intensified in 1997. The most recent event once again pointed out the urgency of a long term management strategy that should be adopted to protect the coastal zone and in turn ensure coastal tourism in the region. It is also to be noted that most of the biota once recorded as common in Digha Coast have disappeared along with intensification of tourism and resultant increased dumping of untreated waste water and garbage. As such, even without quantitative data the impact of unplanned tourism and interventions on the natural process could be seen in both biological and physical changes of this coastal zone.

The Sankarpur Village located within $10 \mathrm{~km}$ from Digha Township was primarily used by fishermen as a fish landing centre. The construction of a fishing harbour led to first major change with direct benefit to the local fishermen. The beach-line of Sankarpur was, however, totally protected and closed to tourist traffic. Recent activities like developing Sankarpur as a second tourist resort near Digha has led to another series of unplanned interventions including removal of unsterilized sand dunes and inadequate protection of the coastal vegetation. The pristine beaches of Shankarpur has clear marks of increasing tourist traffic in the form of littered garbage, much of which are non bio-degradable. The marine life on Sankarpur beach, specially the red crabs, which were very common, are fast disappearing. The newly constructed hotels (more than 10 in a $2 \mathrm{sq} \mathrm{km}$ area) and nearly 2.5 to 3 lakhs tourist per year continue discharge untreated wastewater and dump garbage without any regards for the environment. These activities along with the activities at the fishing harbour are likely to have perceptible impact on the coastal areas of Shankarpur.

The sustainability of tourist traffic would only be ensured with an appropriate land use plan and adequate regulatory control over commercial activities within 500 meters of high tide line. The long awaited effluent treatment plant at Digha is now reported to be under construction; the master plan for Sankarpur should immediately be framed with adequate provisions for environment protection with a supporting surveillance system. The necessity of such a planning has also been clearly demonstrated in the studies conducted by GSI.

\section{B. Tajpur - Mandermoni-Dadanpatrabarh Tourist Sector:}

Tajpur is the latest addition in tourist map of Bengal. The prime attraction of Tajpur is its pristine sea beach fringed with a dense forest of tamarisk trees. The beach is infested with infinite number of red crabs which play hide and seek in the sand. Their presence makes the beach look crimson. There are fishermen's villages in the vicinity, where one can observe the mundane life of fisherman. Just $1 \mathrm{~km}$ away is a lagoon with pleasant surroundings. From Balisai, shared motorised rickshaw (diesel (local name 'kata oil') driven) van (unauthorised) carries 6-10 passengers to Tajpur in 10 mins. Tajpur offers various adventure sports options like para-gliding, rafting, rock-climbing and other activities.

It was primarily a fishermen beach and indigenous salt making units exist there since the pre-independence era. For the development of tourist destination, appropriate infrastructures have been gradually developed with good accommodation facilities (more than 40 hotels and resorts) and pressure of 180000 to 2 lakhs visitors per year destroyed traditional land use pattern and forest, shrubs, natural habitat of different faunas. 


\section{International Journal of Science and Research (IJSR) \\ ISSN (Online): 2319-7064 \\ Index Copernicus Value (2013): 6.14 | Impact Factor (2015): 6.391}

Mandermoni-Dadanpatrabarh is one of the longest hard sandy beach, lies between 13 to $14 \mathrm{~km}$. The area had all natural resource to tourist attracts demarcated by millions of red crabs, sand dunes, screw pines, seasonally visited by thousands of local traditional fishers and seasonal channels offers some places with natural habitat for birds. It was a small fishing hamlet until a decade ago. At present the tourist attraction shifted to Mandarmani from DighaSankarpur, due to her pristine natural beauty made it irresistibly attractive to beach lovers, so the moneyed people or hotelier merchants to attracts the fishers and farmers who are land holders adjacent to the coast to transfer their holdings in favour of their and then they managed local panchayet and political power to issue approval for building plan. It has now become more of a hunting ground for coastal land sharks. Drawn by the steady flow of tourists and pressure of more than 4 lakhs visitors per year, several hotels (Completed more than 135 hotels and nearly 25 under construction) have come up, all sorts of concretization materials were piled up on the beach and beach has turned into a main road which is one rare diesel driven motor (unauthorised) able beach with disturbing the ecology of the inter-tidal zone.

\section{Juneput to Dwariapur-Petuaghat tourist sector}

The calm, wide, long (longer than Digha) and serene beach of junput is lined by the dense casuarinas forest on one end towards the Gopalpur- Kadapara fishing village and the vast sparkling expanse of water on the other. Sunrise in Junput is a treat to the eyes of the visitors. From Petuaghat, walk for 3-4 km and you will reach Dariapur. There is lighthouse and a famous old temple-the temple of Kapalkundala, while Bankim Chandra Chattopadhyay was Deputy Magistrate of Contai, he wrote his famous novel Kapalkundala in the background of this temple. In the old days there was a small but busy sea port at Hijli. But the area has little tourist potential (more than 10 hotels found and 60 to 70 thousand tourist per year are visited the places) due to bad smell from huge amount of dry fish, fishing port and harbour and the Dept. of fisheries of west Bengal government run the area as fish museum, fish cultivation mainly for spawn and research centre.

\section{Impact of tourism activities on Coastal Environment of Purba Medinipur}

Tourism is the temporary movement of people to destinations outside their normal place of residence and work, the activities undertaken during their stay in the destinations, and the facilities created to cater to their needs (Matheison and Wall, 1982). In fact tourism is a multifaceted phenomenon which involves movement to and stay in destinations outside the normal place of residence. Tourism has two basic aspects i.e. the supply of facilities and the demand for participation. Supply and demand interact to produce the pattern of tourism, which may be defined as spatial and temporal incidence of tourism development. Tourism development takes many forms, as the interactions between supply and demand occur at a variety of scales reflecting the vacation length, the distance that can be traversed, the types of activities involved and the tourist motivations. Therefore, it is considered that an understanding of tourism development process will escort to a greater awareness and fuller command of how places change or may be change as tourism is established or expanded.

Basically travel and tourism is related to human urge to know more about the concept or area of one's choice for his benefit and enjoy the environment. Thus tourism is an activity of academic as well as socio-economic nature having various ramifications. The most vital of them is its impact on ecology which governs the environment and thus the entire biological system of species and socio-economic as well as cultural lifestyle of the people.

Such a development took place without appropriate land use planning. The Geological Survey of India in its report on the Digha coastal belt pointed out that the active processes of erosion and accretion have been accelerated by several manmade interventions including removal of sand dunes, leading to mushrooming of construction near the coastline. The exact impact of tourism on the coastal belt of Digha cannot be quantified but, the continuing dumping of solid waste and raw sewage in the coastal water bear testimony to an alarming situation which increases with every tourist season. The Digha-Junput coastal tract is being eroded by sea-water resulting in lowering of the beach and recession of the bank. The rate of erosion has been found to be about 17 meters per year at some parts. Besides erosion, beach lowering (submergence) by about 15 to $20 \mathrm{cms}$ per year appears to continue unabated (Bhattacharya S, 1992). Apart from coastal erosion caused by wave actions and storms, removal of sand for construction of roads and hotels, exploitation of Casuarinas trees on the dune-tops for fuel wood and building materials also cause destruction of sand dunes and erosion of beach. Artificial methods of beach protection at some places also accelerate coastal erosion elsewhere. Coastal accumulation is occurring at Shankarpur. Increasing pressure of human activities on the Hugli unstable coastal zone has been assessed by IIT, CSME and GSI during last 15 years, but no effective action plan for controlling the phenomenon is yet visible.

\section{Growing Coastal Tourism and its impact on Environment in Major Tourist Destinations of Coastal Purba Medinipur}


International Journal of Science and Research (IJSR)

ISSN (Online): 2319-7064

Index Copernicus Value (2013): 6.14 | Impact Factor (2015): 6.391

\begin{tabular}{|c|c|c|c|c|c|}
\hline \multicolumn{2}{|c|}{ Destination } & $\begin{array}{c}\text { Period of } \\
\text { Emergence }\end{array}$ & $\begin{array}{l}\text { Site and } \\
\text { Situation }\end{array}$ & $\begin{array}{c}\text { Tourist Carrying at } \\
\text { present }\end{array}$ & Impact \\
\hline \multirow[b]{2}{*}{$\begin{array}{l}\text { DIGHA \& } \\
\text { Surrounding }\end{array}$} & Old & Late $1950 \mathrm{~s}$ & Water front & \multirow{2}{*}{$\begin{array}{l}\text { More than } 10 \text { lakhs } \\
\text { visitors per year } \\
\text { including day tripper } \\
\text { and more than } 480 \\
\text { accommodation } \\
\text { facilities including } \\
\text { resorts, hotels, guest } \\
\text { houses etc }\end{array}$} & $\begin{array}{l}\text { Shore line water table change, sea beach Vanishing, } \\
\text { Failure sea guard wall structure, flooding and } \\
\text { inundation and anthropogenic pollution etc. }\end{array}$ \\
\hline & New & Mid 1980s & Back shore & & $\begin{array}{c}\text { Built up Dune Surface but erode sand dunes by } \\
\text { wind action due to remove casuarinas forest in } \\
\text { large scale for converting the land into urban } \\
\text { habitat. }\end{array}$ \\
\hline \multicolumn{2}{|c|}{ Sankarpur } & $\begin{array}{c}\text { 1990s and } \\
\text { onward }\end{array}$ & $\begin{array}{l}\text { Low land behind } \\
\text { the Dune Barrier }\end{array}$ & $\begin{array}{c}\text { More than } 10 \\
\text { accommodation } \\
\text { facilities and } 2.5 \text { to } 3 \\
\text { lakh visitors per year. }\end{array}$ & $\begin{array}{l}\text { Reduced beach width and erode dune in massive } \\
\text { scale. Geo-Tube concept failure so storm tide } \\
\text { caused flood and salty and marshy land formed, } \\
\text { damage agricultural field. }\end{array}$ \\
\hline \multicolumn{2}{|c|}{ Tajpur } & 2003 and onward & Back shore & $\begin{array}{c}\text { More than } 40 \text { hotels } \\
\text { and resorts facilities are } \\
\text { available and pressure } \\
\text { of } 180000 \text { to } 2 \text { lakhs } \\
\text { visitors per year } \\
\end{array}$ & $\begin{array}{c}\text { Built up Dune Surface in some parts of the area } \\
\text { (Eastern part) but erode sand dunes and coastal line } \\
\text { (Western part) by wind and Strom Wave action due } \\
\text { to remove casuarinas forest in large scale for } \\
\text { converting the land into urban habitat. }\end{array}$ \\
\hline \multicolumn{2}{|c|}{$\begin{array}{l}\text { Mandermoni- } \\
\text { Dadanpatrabarh }\end{array}$} & 2000 and onward & Back shor & $\begin{array}{c}\text { Pressure of more than } 4 \\
\text { lakhs visitors per year } \\
\text { and several hotels } \\
\text { (Completed more than } \\
135 \text { hotels and nearly } \\
25 \text { under construction). }\end{array}$ & $\begin{array}{c}\text { It has now become more of a hunting ground for } \\
\text { coastal land sharks. Beach has turned into a main } \\
\text { road. And destroyed traditional land use pattern, } \\
\text { Occupational structure and forest, shrubs, natural } \\
\text { habitat of different faunas basically vandalising the } \\
\text { habitat of red crabs. }\end{array}$ \\
\hline
\end{tabular}

Source: Field Study

\section{Ecotourism as a Remedial Measure for the Development of Tourist Destination And Conservation of Biodiversity to the Tourist Destinations of Purba Medinipur:}

\section{i) Concept of Ecotourism}

From the recent past, world tourism has emerged as a very big industry. It provides employment to a large number of people and contributes to national economy as a big way while damaging the natural environment too. For this reason, after 1980s the concept of the eco-tourism has been popularized rapidly by the HECTOR CEBALLOS LASCURAIN (Maxican environmentalist) in 1983 initially the term (eco-tourism) used as-"Travelling to relatively undistributed and uncontaminated natural areas with the specific objective of studying, admiring and enjoying the scenery and its wild plants and animals, as well as any existing cultural manifestations (both past and present) found in these areas."

So eco-tourism is nature based tourism and it is an effective instrument for enhancing method of conservation of environment, many income generating activity (through earning revenue, foreign exchange, hotel business, commodity selling, hotel boy service, guide, making hand-crafts etc.) of the local population, economic benefits of the host communities of the state or country and rejuvenation of the culture and tradition there by facilitating overall development. It also give us that ecotourism is a positive source of fascination for man and one of the causes of his psychological peace, mental solace and enjoyment and it rejuvenates man's sprit to explore nature again and again, revives his vitality and gives fillip to his energy after been churned out by the routine work of his monotonous life.
According to world tourism organization 'Tourism that involves travelling to relatively undisturbed natural areas with the specified objects of studying admiring and engineering the scenario and its wild plant and animals, as well as any, existing cultural aspects fund in these areas is defined as Eco-Tourism'. Now a days, the tendency to the established of eco-tourism industry is increasing worldwide.

So, Eco-tourism is an advanced thought on development of tourism in the natural surroundings of forest, wild life, coastal sceneries, coastal land forms, Mountain sceneries, Sanctuaries, National Park and different aquatic life, local population preserving the scenic beauty of the area. The beauty of this concept is the active participation of people inhabiting in an area for promoting tourism without degrading the natural surroundings. In this way many income generating activity for the local population will emerged and they will be benefited economically and socially also by mixing with the domestic and foreign visitors. The term was used to describe nature based travel to relatively undistributed natural areas with an emphasis on education. The concept has however, developed into a scientific approach to the planning management and development of tourism, products and activities. It can be defined as to attritions that contribute to their conservation, respect the integrity and local commodities and enhance the tourists understanding of the natural attraction and its conservation. 


\section{International Journal of Science and Research (IJSR) \\ ISSN (Online): 2319-7064}

Index Copernicus Value (2013): 6.14 | Impact Factor (2015): 6.391

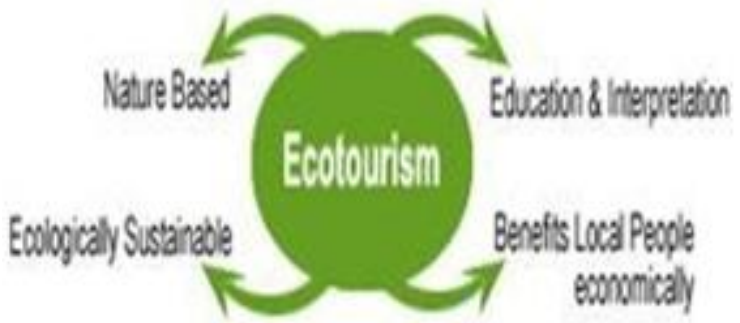

ii) Prospects to established ecotourism:

\section{* Presents romance with sun, sand and sea.-}

The coastal tracts (Specially sea-beach) of Purba Medinipur presents gorgeous source of scenic beauty where the sightseer play and enjoy romance with sun, sand and sea in the sea beaches ( well-liked places are - Digha,Sankarpur, Tajpur,Mandarmoni,Juneput etc.). The mentioned places of coastal tracts of Purba Medinipur are offers their individuals characteristics as wide, hard and flat beaches where have presents rolling seas, sand dunes, casuarinas forest, red crabs, eye catching beautiful scenario, remarkable variety of aquatic and forest life. Which are ultimately attracts tourist in that coastal areas.
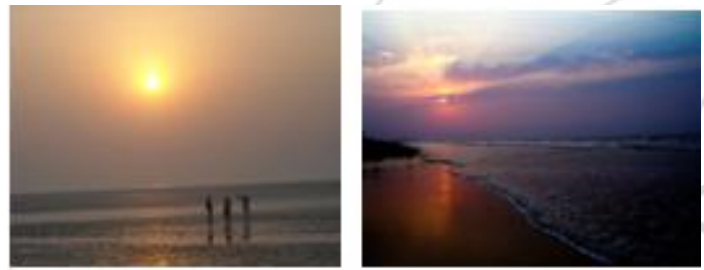

Scenic beauty at New Digha

*Maintained high degree of Bio-diversity:

Coastal region of Purba Medinipur is a land of hope, a hope to care for the green and save nature. This region is a transitional zone in-between sea and land where the mangrove forest are whispering, sea are roaring, the flora and fauna are blooming and where visitors can rejuvenate yourself in the company of sand, sea and sun in the pristine open air. Each part of the coastal region of Purba Medinipur is nothing short of spectacular view wearing a green blanket the coastal area seems like an emerald of WB. Among these rich flora and fauna are the major eco-tourism resources, which help to increase the glamour of the eco-tourism industry in Purba Medinipur as well as W. B. coastal region. In coastal region of Purba Medinipur as well as W.B, there are varieties of trees, shrubs, climbers, herbs; medicinal plants etc. which are create a colourful spectrum of bio-diversity. Except these, many endangered flora and faunas are also the chief source of tourist attraction, and, although, eco-tourism is the nature based tourism so it can be said that rich flora and fauna also make a way to ripen eco-tourism industry in Purba Medinipur as a part of West Bengal coastal region.

\section{* Employment opportunities}

Sustainable development of eco-tourism is of immense significant in generating the employment opportunities of many semi-skilled and unskilled people, particularly in remote and underdeveloped areas. A large number of women and young people are engaged in hotel, transport services, travel agencies, making and selling, hand crafts, cultural activities and other tourism-related tasks.
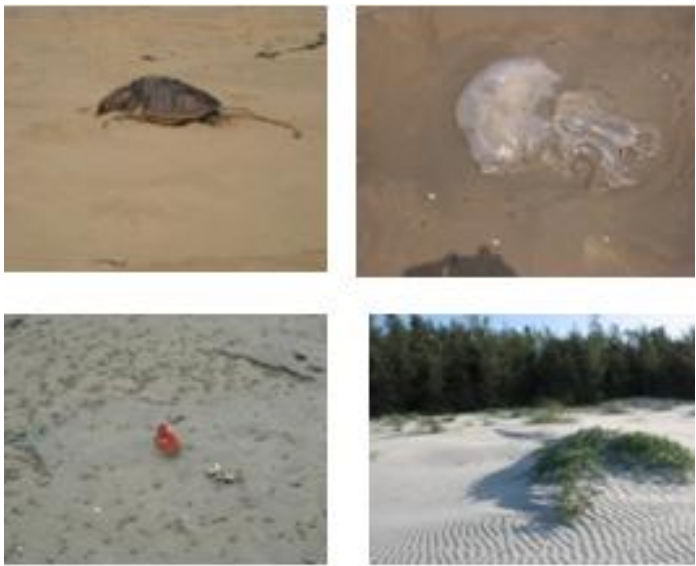

A Signature of high degree of Biodiversity

The distribution of population across districts shows that, the total share of working population is $34.57 \%$ of the total population of which $89.44 \%$ are male workers and $10.56 \%$ are female workers. About $65.43 \%$ of total population are unemployed who are totally dependent on $34.57 \%$ of total workers (Marginal + Main workers).
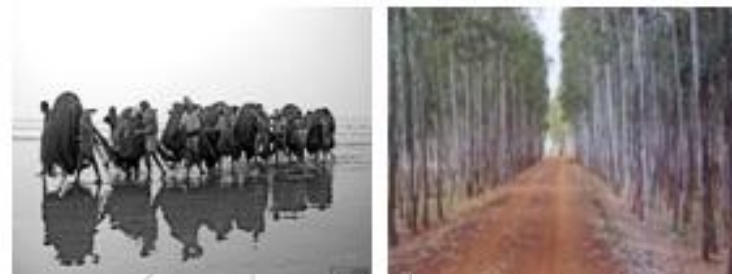

Fishing \& fire wood collection facilities

\section{*Pleasant weather condition}

Pleasant warm weather condition like tropical monsoon climate with an average annual rainfall of $1500 \mathrm{~mm}$ and maximum air temperature is around $35{ }^{\circ} \mathrm{C}$ and the minimum is $13{ }^{\circ} \mathrm{C}$, which affected by land breeze and sea breeze, are attract the tourist round the year.

\section{iii) Constrain to promote ecotourism}

Many small sandy islands and mudflats mark the river channels and most of tourist places in Purba Medinipur coastal area get completely inundated during high tide. Industry and tourism has established a strong presence in the area between the Subarnarekha river on the west and the Hugli in the east. Agriculture is a predominant activity in this region

In this region, impacts of human activities come through (a) diesel driven fishing boats through release of hydrocarbon due to lack of maintenance), (b) fishing harbour activities, (c) aquaculture farms and (d) agriculture, none of which has been properly assessed. Other economic activities, besides fishing and agriculture, include honey collection, wood cutting, Salt pan activity in Dadanpatrabar area and Brickfields are also mushrooming along the river and backwater courses. Tourism is a major contribution to the economy of the coastal zone. Tourism activity invariably leads to accelerated road transport (diesel driven), hotel industry and illegal encroachment by small traders. Each of these components has a direct impact on environment 


\section{International Journal of Science and Research (IJSR) \\ ISSN (Online): 2319-7064 \\ Index Copernicus Value (2013): 6.14 | Impact Factor (2015): 6.391}

quality of land, air and water. So, now days the coastal plain of Purba Medinipur as well as West Bengal suffers by many problematic issues which have create conflicts between various resource users and interest groups,

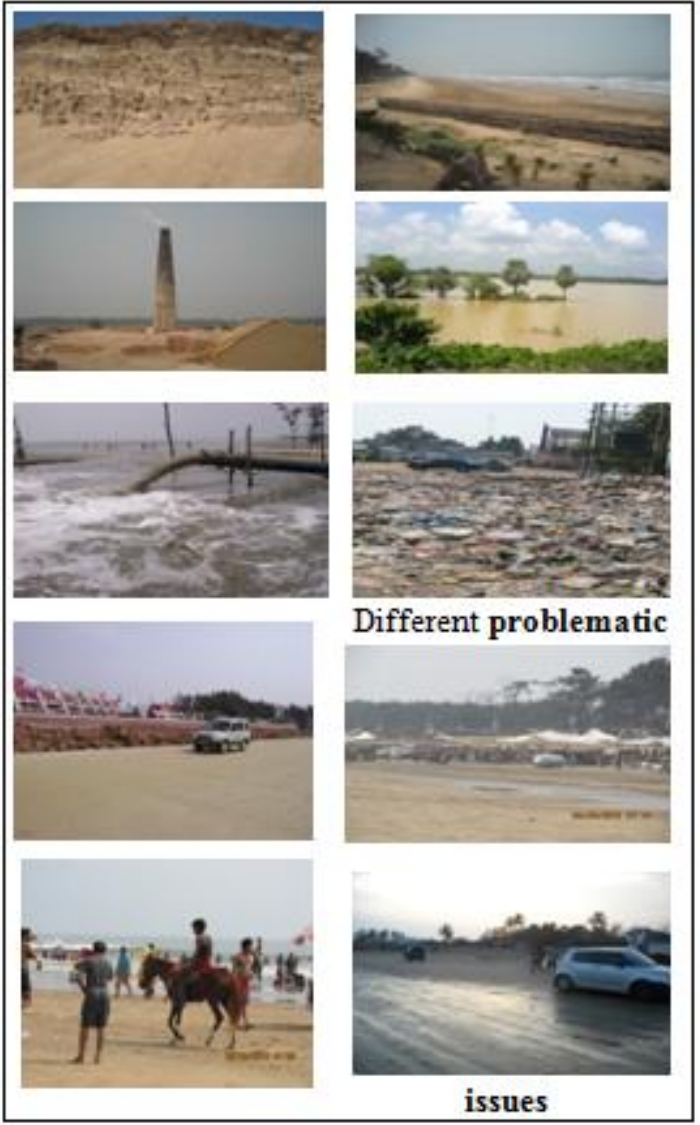

between developers and ecologists/environmentalist, Engineers and geoscientists and land owners and economists in Purba Medinipur of West Bengal as well as India also.

Beside the above the risk has been increased considerably in the interactive zone of human activities and coastal hazards. Only the burning issues are mention below, which are resist the emerging dimension of coastal ecotourism in Purba Medinipur coastal tourist destination as well as also West Bengal coast. These are i) Sea level rise, ii) Shore-line erosion, iii) Storm/cyclonic hazards, iv) Large scale urban encroachment, v) coastal recreational exploitation, vi) brick fields on coastal flood plain area, vii) lack of knowledge about EIA law and order, viii) lack of interest to implement the CRZ acts/ Implementation of law and order by the concern authority and ix) Local political Interference.

\section{Conclusion}

Coastal tourism is strongly depending upon natural aspects (like landscape, climate, and ecosystems) and cultural aspects (historic and cultural heritage, Arts and Crafts, traditional resources etc.). It encompasses activities that can only be carried out in particular areas and a specific condition. The Fragile landscape of the coastal tract of Purba Medinipur and fully of floras beauty presents high quality attractions for the tourist.
The development of coastal tourism is tied to the concept of sustainable tourism. There is need to understand the complexity of the linkage between social and cultural system.

The coastal land of Purba Medinipur is $60 \mathrm{~km}$ long marked by Sand dunes, beaches, long shore current and low vegetation coverage. The fine sand beaches of Purba Medinipur have gentle foreshore slopes and provide a firmly packed hard sand surface for safe walking, playing, bathing and car driving. The Purba Medinipur coastal tract presents different habitat with contrasting ecological features. The Major habitats are Talsari, Digha old and New, Sankarpur, Chandpur, Jaldha, Tajpur, Mandemoni-Dadanpatrabarh, Juneput, Khejuri - Hijli and Haldia surrounding also.

All the ecotourism places are full of natural habitats. Digha old and New was health resorts under the British rule. It is also weekend and popular beach resort in Purba Medinipur as well as also W.B., Sankarpur is a well known fishing harbour and newly develop tourist spot where as the Mandermoni-Dadanpatrabarh is longest drivable beach in India and geomorphologically a relatively low waves beach. Junput is known as fish landing centre and a good patch of mangroves has come up in the intertidal zone. Tajpur is a sea beach fringed with a dense forest of Tamarisk trees, also infested with infinite number of red crabs whose present's makes the beach looks like crimson carpet.

But Lack of co-ordination, less involvement and little incentive of the local people in terms of income generation local panchayat and political power to support and issue approval for building plan at adjacent to the shore due to lack of awareness about CRZ and EIA rules. Proper management of the coastal ecotourism destinations becomes highly appreciable and there is need off alarming and consciences among the local people. The development of immense potential of coastal ecotourism should be tied with the concept of sustainable tourism. There is need to understand the complexity of the linkage between social and cultural systems. There is need to focus our efforts to promote local tourism in the coastal tract of Purba Medinipur along with awareness campaign for conservation of natural flora and fauna.

The rapid growth of coastal tourism of Purba Medinipur as well as W.B. writ in the last 20 years is one of the major reasons for the urban infrastructural development of these coastal areas and consequent coastal environmental problems. the questions of sustainability is particularly important in the context of coastal tourism, which is an activity at the interface of mankind, land and water, coastal tourism, therefore, is facing the challenges of balancing tourism's economic advantages with maintaining environmental sustainability and the inevitable change of its own character with the progress of time. The sea beaches perform, in this context, a fundamental role where the issues related to planning and management are increasingly more important when it comes to the implementation of sustainable development strategies.

Purba Medinipur Coastal Zones as well as West Bengal Coastal zones hold an unenviable position as regards a 


\section{International Journal of Science and Research (IJSR) \\ ISSN (Online): 2319-7064 \\ Index Copernicus Value (2013): 6.14 | Impact Factor (2015): 6.391}

tourist destination. Lack of proper co-ordination between the Tourism Department and the West Bengal Tourism Development Corporation (W.B.T.D.C.), dearth of infrastructural facilities and improper planning, wild cat strikes and road blocked agitation, paucity of reliable statistics and dearth of proper and accurate information and publicity materials all contribute to the sorry state of affairs in the field of tourism promotion. While many of the state in India have made substantial progress, absence of reliable and up to date statistical information on tourist arrivals, accommodation available, transport accessibility, socioeconomic profile and behavioural attitudes of the visitors have been marked lacking in coastal Purba Medinipur as well as W.B. also, than other parts of W.B. tourism destinations. In order to make the tourism policy more effective and pragmatic, the need for conductions comprehensive tourist surveys so as to enable a better understanding of tourist profiles, problems, needs and preferences become absolutely necessary and crucial.

\section{Acknowledgement}

I Pijush Kanti Dandapath, as principal investigator, gratefully acknowledge with gratitude the financial support from the U G C Minor Research Project Scheme, India under the sanctioned memo no. PSW-122/13-14(ERO), ID No. WV6-001 dated $18^{\text {th }}$ March 2014.

\section{References}

[1] Biswas (Bera), A and Bera, D. (2009):Ecotourism in dooars of West Bengal: Its Prospects, Problems and Proposals. Geographical Review of India. 71(3): 264-

[2] 268.

[3] Butcher, J. (2005): The moral authority of Ecotourism CABI Publishing, Wallingford, 5-10

[4] Cater, E. And Lowman, G. (2013): Ecotourism in the third world-problems and prospects for sustainability in Ecotourism, a sustainable option? United Kingdom, Jhon Willey and Sons, 25-30

[5] Chakraborty, S. K. (2010): Coastal Environmentof Midnapore, West Bengal : Potential Threats and Management. Journal of Coastal Environment. 1(1): 27-40.

[6] Dandapath, P. K., and Mondal, M. (2013): Urbanisation and its Impact on Coastal Ecotourism in West Bengal. International Journal of Science and Research. 2(1): 114-119.

[7] Dandapath, P.K., Oraon, G. And Jana, S.R.,(2016): Tourism Caused Jeopardize of Biodiversity: A Case Study on Mandermoni -Dadanpatrabarh Coastal Tourist Destination in PurbaMedinipur District, West Bengal, India. International Journal of Experimental Research and Review (IJERR), Vol.4, 40-44.

[8] Kaushal, P. and Sharma, S. (2011): Ecological and Environmental Impact of Tourism, Kanishka Publishers \& Distributors, New Delhi.

[9] Mallya, A. (2006): Eco-tourism and the community participation, Authors Press, New Delhi.

[10] 9.Mill, Robert Cristle and Morrioon, A.M., (1985): The Tourism System, An Introductory Text, Banticehall International Inc. New Delhi, 25-r30
[11] 10.Mondal, M., Dandapath, P.K., and Shukla, J. (2013): Emerging Dimension of Coastal Ecotourism Resources along the Coast of West Bengal. International Journal of Advanced Research in Management and Social Sciences. 2(1): 58-73.

[12] Paul, A. (2002): Coastal Geomorphology and Environment, ABC publication, Kolkata.

[13] Saha, D. (2011): Republic of India: West Bengal Coastal Areas Development Project (Inception Phase Concept Paper).

[14] The Draft Environmental and Social Assessment Report (2009). Prepared by consultant, Center for Environment and Development, Thiruvanathapuram

\section{Author Profile}

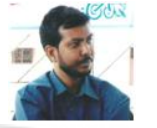

Pijush Kanti Dandapath received educational degree in and outside of West Bengal (B.A. Honours in Geography from Trivenidevi Bhalotia College, under Burdwan University, Ranigaunj, West Bengal, M. A. in geography from C.S.J.M. University, Kanpur, U.P., India, and M. Phil from Calcutta University, Kolkata, West Bengal, India). He is now working as an assistant Professor of Geography and acting as Head, Dept. of Geography at Bajkul Milani Mahavidyalaya, P.O.-Kismat Bajkul, Dist.-Purba Medinipur, West Bengal and he is also doing his research work as a Research Scholar under Department of Geography, of Ranchi University, Ranchi, Jharkhand, India. At present he is also engaged as principal investigator in a Minor Research Project Work with the financial support of UGC and also has done the project work (CoInvestigator) under West Bengal Biodiversity Board at Saltlake, West Bengal, India. In recent he is also acting as executive editor of a reputed online journal.

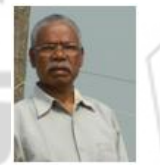

Dr. Gonne Oraon received his $\mathrm{Ph}$. D. Degree from Ranchi University, Ranchi, Jharkhand, India. He has successfully done his duty as Principal-in-charge at KCB College, Bero, Ranchi, Jharkhan, in a long term and now he is working as an Assistant Professor and acting as Head, Department of Gegraphy at KCB College, Bero, Ranchi. At present more than 3 Research Scholar are engaged under his supervision in different field. 